\title{
21 Contested development(s)? The possible contribution of the African Independent Churches in decolonising development
}

\author{
A South African perspective
}

Nadine Bowers-Du Toit

\section{Introduction}

Bompani $(2015,105)$ notes that despite the fact that African Independent Churches were often seen as not critical enough towards the then South African Apartheid state, 'more recent analyses highlight how AICs played a strong and supportive role among Black Africans in particularly deprived economic situations where there was often little support from mainstream development organisations'. It was, in fact, Evans, Bekker, Cross and Oosthuizen's 1992 study entitled 'Prophets for the poor: African Independent Churches' which was one of the first to outline the way in which the 'energies and activities of these churches could be linked to development initiatives' (1992, 33). More recently, Öhlmann et al. (2016) have highlighted the potential of African Independent and Pentecostal Churches as development actors for partnership with European development agencies.

Most of these authors highlight the potential of African Independent Churches as development actors for their more pragmatic contributions such as the development of social capital, their potential for small scale community upliftment projects and the promotion of moral values/ethics. My task in this contribution, however (although I will touch on these later in this chapter), is to conversely identify how the assumptions and practices, which undergird development itself, in conversation with African Independent Churches' grassroots praxis could unearth points of critique 'from below' to decolonise current western development praxis. The chapter, therefore, attempts to point out both the congruency and incongruity of the relationship between development and the Independent Churches in South Africa as well as to uncover their possible role in decolonising development as we know it within an African context. The latter implies a 're-centring' of development - a rejection that a western praxis of development should be the sole departure point in African development praxis. In the words of African scholar Achille Mbembe $(2015,18)$ 'decolonisation (a la Nugugi) is not about closing the door to European or other traditions. It is about defining clearly what the centre is'. In this sense the chapter is not an attempt to simply romanticise or fetishise the African Independent Church 


\section{Nadine Bowers-du Toit}

phenomenon, but rather an attempt to de-centre the notion that western development practices and assumptions - often undergirded by modernity should be uncritically applied as 'universalistic, neutral and objective' in its departure point (Grosfoguel 2007, 2011).

\section{AICs as promotors of African culture}

This section will outline some complexities around the term 'African Independent Churches' and highlight aspects which will be key to later analysis. Mbiti himself saw the rise of the African Independent Churches as 'an attempt for Africans to engage with African issues and context seriously' (Mbaya and Cezula 2016, 5). Masondo $(2014,11)$ highlights in particular the notion that these churches have played 'a key role as preservers, developers and promotors of African culture', and notes that 'these churches are a socio-cultural protest using precolonial African resources. They reject definitions of Christianity based on Western capitalist models'. Indeed, they have even been identified as providing cultural and symbolic responses to what he terms 'the brutal attack on Africans and their culture'. Prominent scholar of Black Theology, Simon Maimela's (in Masondo 2014, 3) explanation of an African understanding of salvation certainly assists in understanding AICs' theology and praxis:

The reluctance of Africans to break ties with the African Traditional Religions lies in the fact that they are wedded to an African worldview in which salvation is understood in terms of relief or help in times of trouble in this life. Salvation is thus expressed in such acts of healing, driving away evil spirits, empowerment of the individual self, the promotion of fertility, and success in life's ventures.

The latter denotes the African ontology - where the spiritual is intricately woven with the material - a holistic dimension which Mbaya and Cezula note also speaks to the communal nature of African life $(2016,7)$. The issue of time should also be understood as important to this world view and, therefore, to engagement with the African Independent Churches. Contrary to popular belief, Africans do have a concept of time, but it is understood in terms of an event other than a mathematically calculated period, wherein the past also distinctly defines the 'present reality and tomorrow' (Mbaya and Cezula 2016, 10).

\section{What's in a name? African Initiated or African Independent?}

This contribution focuses on African Independent Churches rather than African Initiated Christianity in its entirety. African Initiated Churches refers to a broader group which 'denotes all churches founded by Africans, in Africa and without direct links to missionary "godfathers"' (cf. Pobee and Ositelu 1998, 55). This definition then includes the Zionist, Ethiopian and Apostolic churches as well as the (mostly) independent Pentecostal-Charismatic 
Churches. ${ }^{1}$ African Independent Churches, on the other hand, are identified as a smaller sub-group consisting largely of the Zionist, Apostolic and Ethiopian groups and excluding the Pentecostal-Charismatic Churches.

Both groups certainly share some key 'markers' such as indigeneity and both indeed 'exemplify the African struggle for self-identification and self-realisation" (Masondo 2014, 3). In a strange way one could even argue that those Pentecostal and Charismatic indigenous churches who profess the prosperity gospel which is founded both on a promotion of health and wealth, but also on the empowerment of the individual self - are precisely drawn to this theology as a result of an African worldview. Black African students in my university classes over the years have certainly suggested this as counter to my critique of the prosperity gospel as 'preying on Africans'. Nevertheless, even though many of the largely independent Pentecostal/Charismatic sector may be Indigenous Churches, they are still deeply influenced by western notions of the prosperity gospel. The latter perhaps not so much then being a case of missionary godfathers - but perhaps more one of tele-evangelist stepfathers? In addition, many of these Pentecostal/Charismatic groups might even balk at the idea of being grouped with African Independent Churches as they may consider them 'beyond the pale': syncretic and perhaps not even as part of Christianity at all (cf. Kealotswe 2014, 239).

\section{Towards problematising development}

The notion of development as we understand it today is itself a contested one with many theories over the years seeking to provide theoretical frameworks to engage issues of poverty, marginalisation and inequality. Perhaps the most commonly held understanding of development remains that of the Modernisation Theory, a macroeconomic theory which upholds the supremacy of economics and the liner development of all majority world/global South societies from 'underdeveloped', third world societies to developed western societies. In this understanding development is unilineal and based on the assumption that 'west is best'. Local and indigenous knowledge is also regarded as less valuable than western knowledge systems and development and modernisation are conflated (Litonjua 2012, 27). Although this notion of development is no longer 'in vogue' within development circles, it still largely undergirds neo-liberal notions of development, which continue to permeate both development theory and practice today. McEwan $(2008,105)$ for example notes that 'despite persistent critiques the notion of development envisaged by modernisation has been reinvented in contemporary neoliberal discourses'.

Other theories such as Dependency Theory, Another Development, NEIO and Self-Reliant Development all followed with little traction, however, towards the 1980s the notion of People Centred Development was popularised by development scholars such as David Korten which saw a move from macroeconomic approaches towards a grassroots approach (cf. Bragg 1987, 28-38). In this more radical approach the locus of development is the local community 


\section{Nadine Bowers-du Toit}

and its people who are to participate in development. In the words of Korten $(1990,67)$ development is then defined as:

... a process by which the members of a society increase their potential and institutional capacities to mobilise and manage resources to produce sustainable and justly distributed improvements in their quality of life consistent with their own aspirations.

People were, therefore, to be empowered to participate in their own development and to manage and utilise local resources to their own benefit (Swanepoel and De Beer 2011, 38).

More recently Amartya Sen's Capabilities Approach has gained popularity in

seeing development as a process of expanding people's human capabilities.... In the field of development 'capabilities', according to Sen, do not refer to income, resources, goods, emotions or the satisfaction of preferences. It refers to what people are effectively able to do and be or the freedom 'to enjoy valuable beings and doings'.

(De Beer and Swanepoel 2011, 39; cf. Sen 1999)

In the past 15 or so years, development discourse has been popularly forefronted by the UN promoted Millennium Development Goals (2005-2015) and the more recent Sustainable Development Goals launched in 2016. These goals, as determined by the $\mathrm{UN}$, are promoted as issue-based indicators of the development of respective nations, with the notion that should these be addressed, poverty, marginalisation and environmental degradation will be eliminated forever (cf. Sachs 2012).

While many of the later approaches to development appear to promote notions such as people-centred development, which are said to place the members of the community at the centre of their own development, many understandings of development are still undergirded by western notions of progress, secular and individualistic human rights and positivistic measurements (Mtata 2013, 31). The latter appears to suggest that there is a clear need for delinking the notion of development from the foundation of modernity on which the vast majority of current approaches to development rest (Mignolo 2007, 450). In this respect, scholars such as Mignolo (2007) and Grosfoguel (2011) have argued for critical border thinking, which takes 'seriously the epistemic perspective/cosmologies/insights of critical thinkers from the Global South thinking from and with subalternized racial/ethnic/spiritual/sexual spaces and bodies and which rejects the notion of the West being developed and the rest underdeveloped' Grosfoguel (2011). Wutich and Beresford (2015, 3) identify three development ideologies currently at play in their context of Latin America: neo-liberalism, ${ }^{3}$ alternative modernisation (which appears to renationalise industry, regulate trade and the influences of the West and promote indigenous ideology at state level) and decolonialism. They argue that while the alternative modernisation approach may address some of the critiques around 
neo-liberalism, it is not enough and should be augmented by decolonial approaches at grassroots level. These decolonial approaches, it is argued, are 'typically aligned with grassroots social movements, promote non-capitalist economies, collective forms of governance, deep ecology and indigenous worldviews' (Wutich and Beresford 2015, 5). Grosfoguel $(2009,32)$ goes as far as to suggest that 'development projects that focus on policy changes at the level of the nation-state are obsolete in today's world-economy and they lead to development illusions'. These 'development illusions' can only be confronted by recognising the power dynamics with regards to the flow of wealth from the North to the South and calling for global decolonial solutions.

The UN goals (Millennium Development Goals/Sustainable Development Goals), for example, while not wrong in and of themselves are once again a topdown list of global indicators imposed on national and then by design on local contexts - priorities set outside of context and often used by donors in determining funding priorities. Indigenous culture and knowledge systems are also often undervalued in development discourse and practice - which with its often western donor-driven agendas in conflict with local worldviews, issues and priorities has the danger of favouring what in development is termed an 'outside in' rather than an 'inside out' approach to development. According to August (2013, 79):

Development must be appropriate to the culture that is to be transformed. Nonetheless, modernizers have all too often ignored customs and social patterns in an attempt to bring material benefit to those who were regarded as 'backward.' They regard local tradition as an obstacle to change and technology without understanding the rationality of society's accumulated wisdom.

The results have been cultural imperialism and the destruction of indigenous values and even entire cultures. Particularly where donors and large-scale funding are involved, measurable outcomes are demanded as part of the accountability required - the meeting of which increasingly requires professionalised development staff with knowledge of logic frameworks and programme design and Monitoring and Evaluation (M\&E) skills. In some of the grassroots FBO's with which I work the employment of an individual with these skills is even demanded as a pre-requisite for funding by some donors. These power dynamics - often flowing from the global North to the global South - are increasingly being recognised by development thinkers. However, I would contest whether in much of development praxis 'the subalterns can truly speak' (Spivak 1994).

\section{Decolonising development? The possible contribution of the African Independent Churches}

This section explores key distinctives of development praxis and its underlying assumptions and brings it into conversation with the praxis of African Independent Churches. Grosfoguel $(2009,30)$ argues that a decolonial critique problematises the centring of western knowledge systems and power and argues that 


\section{Nadine Bowers-du Toit}

'subaltern identities could serve as an epistemic point of departure for a radical critique of Eurocentric paradigms and ways of thinking'. In this way, an attempt is made in this section towards some pointers in providing a de-centring critique to raise possibilities with regards to current development praxis by moving the locus of the analysis to African Independent Churches as subjects of this contribution.

\section{Restoring the unity of the body and spirit}

The very understanding of development is undergirded by enlightenment thinking and neoliberalism, which places the material and the 'will to power' at the centre of development and is often accused of emphasising 'economic and material wellbeing at the expense of other aspects of human life' (Tomalin 2013, 83). Development is still understood by many as materially focused and although the relevance of spirituality and religion has come into sharper focus in recent years, the alternatives to secular development strategies and critiques offered by religions to 'mainstream development goals' located within a western capitalist system have not been as deeply explored (Tomalin 2013, 83).

Indeed, African Independent Churches take seriously the spiritual world, recognised by Africans as part of daily reality - a reality often 'dismissed as superstition from a western perspective' (Öhlmann et al. 2016, 3). Well-being would, therefore, not be regarded as a purely physical phenomenon - as healing is regarded as holistic - so there is no division between the spiritual, psychological and physical and these interventions are therefore holistic in nature. Öhlmann et al. $(2016,5)$ note for example that healing is a focal point of many African Independent Churches' activities and that this if often seen as a 'process to support and encourage their members to overcome conditions in their lives perceived as a deficit'. Furthermore, their congregations were 'trying to respond to all the needs of their members and communities - spiritual, economic and social' and traditionally understood 'spiritual activities' are understood alongside development activities as development work. They note one church leader as saying that 'spiritual development is part of development' (Öhlmann et al. 2016, 5).

Mission Churches already largely acknowledge the same in recognising that development should address the whole person as well as the role of the spiritual and this has been recognised within the development sector as positive (cf. Myers 2011). Nevertheless, although systems of ethics and the value of particular teachings have been recognised by development scholars as possibly contributing to development, African Independent Churches in this way move the religion and development debate along still further by challenging the very roots of materialism itself as embedded in development. They do this in not only recognising the spiritual but placing as central what Christian anthropologist Hiebert (1982) calls 'the excluded middle' of the supernatural and its role in holistic healing. For African Independent Churches, development cannot truly be attained if there is no holistic healing - this begs the question: how will projects focused only on the material for example be regarded by them? 


\section{Re-centring African values and culture}

In postcolonial development discourse one of its core strategies is to destabilise the 'dominant development discourses of the West on the grounds that these are unconsciously ethnocentric ... and profoundly insensitive to the meanings, values and practices of other cultures' (McEwan 2008, 107). Kritzinger (1990), therefore, provides an interesting critique to early scholars seeking to study the relationship between new religious movements and development in noting that scholars such as Turner and Oosthuizen, while recognising the value of the African Independent Churches, still viewed development largely as 'westernisation'. It is precisely, however, indigenous notions of Ubuntu, healing and of salvation as noted by Maimela, that mark African Independent Churches unique contributions to development. ${ }^{4}$ Masondo $(2014,11)$, as aforementioned, even argues that they address issues of cultural injustice using precolonial resources.

Although Bompani $(2015,106)$, much like Turner and Oosthuizen before her, seems to suggest that 'AICs as an component of associational life among poor communities could shape a relationship with modernity and could therefore play a role within the "modernization" process', she identifies African Independent Churches' development ethos as distinct and unique. It is an ethos which sees local self-reliant development and strong networks of social support ultimately undergirding initiatives such as stokvels, burial societies and other networks which mitigate the risks of events which may produce socioeconomic vulnerability (cf. Öhlmann et al. 2016, 4; cf. Evans et al. 1992, 35). Western development agencies, therefore, seeking to engage these churches should and must not only take note of this tension or, as I believe Bompani does, view it in an instrumentalist manner. They should also seek to understand which aspects of African cosmology may directly work either against their understandings of development or possibly contribute towards enriching it. Projects suggested from outside for example should be aware of African cosmology - especially as it is located within the specific African culture it is seeking to work within.

\section{Promoting grassroots agency}

One of the hallmarks of development practice - despite a move by many scholars to encourage grassroots, participative processes which place the community at the centre of their own development - is the centrality of the development practitioner and professional practice. Even development as practiced by many grassroots NGOs in Southern Africa still sees an expert outsider to the community at the helm of many organisations and projects. In their early study, Evans et al. $(1992,37)$ note for example the very different 'drivers' of development practice between African Independent Churches and larger development agencies and NGOs:

Church members perceive the aims of development differently from the state development agencies and some larger non-governmental organisations 


\section{Nadine Bowers-du Toit}

(NGOs). While these larger bodies concentrate more in large scale development in terms of rational planning and service provision, the churches' range of development activities are influenced by the needs of their members, which are smaller-scale and embody more immediate requirements such as social and financial support.

African Independent Churches' development initiatives are largely small scale and locally driven - 'relying on the skills and qualifications of their members to engage in development activity' $(1992,37)$. Kritzinger $(1990,58)$ notes that much like the base communities in Latin America these churches promote a kind of koinonia which promotes development 'from below', rather than the kind of technocratic, professionalised development practiced by many agencies. In this practice the activities are - at least per people-centred development thinking and research - more likely to be sustainable in the long term as they are owned by the very people who benefit rather than by outside agencies and external development professionals (cf. Chambers 1997, 34-36).

The other aspect of professionalisation is that once again there is the possibility that a western outsider adds to the power dynamics already embedded in development and might I controversially add could become a new form of colonisation (cf. Chambers 1997, 59). One of the strengths of African Independent Churches according to Masondo $(2014,3)$ is that they 'exemplify the African struggle for self-identification and self-realisation' and 'provide an avenue for African self-definition by highlighting what is good about being African and inculcating a sense of pride in that identity'. In this way, they affirm an African understanding of personhood, which is a key component of self-actualisation which again explains why they require little outside intervention.

\section{Local priorities, agendas and support}

This aspect is linked to the previous point in some ways. African Independent Church projects are small scale, self-generated, resourced by local congregants and internally funded. This way of doing development is framed within an understanding that African Independent Churches serve as a home for their members - 'a closely-knit community for its members that acts as a powerful support structure during times of need' (Masondo 2014, 10). African Independent Churches are deeply connected to their own people at grassroots, with leaders noting that their focus was on local issues for this reason.

Issues highlighted by Evans et al.'s 1992 study and confirmed by Öhlmann et al.'s 2016 study is that as the development is largely locally driven by local volunteers there are often few or no 'individuals who can act as brokers with larger organisations to promote development interests' (Evans et al. 1992, 37). Of course, these findings also assume that outside organisations should be included to promote development interests! Larger scale donors, whether they be Northern donors or South African business and state actors require a high level of professionalisation for funds to be disbursed, which as aforementioned 
means that professionals should be well versed in project and programme management skills as well as Monitoring and Evaluation (M\&E). Öhlmann et al. $(2016,11)$ certainly allude to this in their highlighting the fact that 'administrative requirements' in interacting with donors should be kept to a minimum and that programmes be co-financed within their capacity. They still note, however, that although donors seek to be flexible in their requirements churches should be required to obtain qualifications in 'financial management, organisational development and monitoring and evaluation - where feasible even ex ante' $(2016,11)$. It should also be noted that programme and project management together with $M \& E$ are firmly based upon western notions of time and space - which are not (and should not) be understood as universal.

What is not noted in these papers is the pull of donor funding towards donor agendas, which are often driven by global priorities such as the SDG's rather than local realities. Several recent studies note the popular term 'social capital' and even 'spiritual capital' to identify the kind of development done by African Independent Churches and it is precisely, I think, because of the extensive social networks within these communities that these initiatives remain sustainable, as sustainability is not centered on financial capital. Indigenous concepts such as the isiXhosa' word 'umfelandawonye' (which means 'dying together for a common purpose') or the Sotho 'Batho Pele', which means 'people first' calls particularly northern or western understandings of development to account. How will these donors respect the deep solidarity and locality of common purpose? How will they maintain that people, and not programmes and the money which they donate, will dictate the agenda?

\section{Conclusion}

While the critique of western notions of development and its inherent rootedness in the projects of modernity, colonialism and neo-liberalism is not new, in uncovering the congruencies and incongruencies between certain western notions of development and African Independent Churches I have sought not only to affirm the position that African Independent Churches do have an important role to play in development, but that this role extends beyond the pragmatic towards radical critique. African Independent Churches do more than serve development agendas - they are far more complex and operate from completely different assumptions to that of western development agendas as we know them.

In this regard, they have something important to say to western donors and organisations seeking to work on my continent and illustrate that subalternised subjects are capable of conceptualising their own realities. In fact, the article even argues from a decolonial perspective that African Independent Churches can serve as epistemic points of departure to critique and decentre western notions of development (Grosfoguel 2009, 12; 30). Although in many ways it may be argued that the African Independent Churches operate in line with 'people-centred' notions of development, their praxis nevertheless raises interesting questions, possibilities and challenges to particularly western organisations or large donors seeking to 
work with them. These include recentring African values and culture or restoring the body/spirit dichotomy. Furthermore, their praxis in fact fits in directly with decolonised notions of community development, which includes the promotion of non-capitalist economies, collective forms of governance and indigenous worldviews and, therefore, it may be argued that they are a rare example of what decolonised praxis could look like.

The praxis of these subalterns, therefore, speaks and such praxis often introduces yet more complexity to whether such donors and agencies will prove to be successful in engaging development truly 'from below'.

\section{Notes}

1 It should also be noted that while not all African Initiated Churches can be tarnished with the same brush, some of the independent Neo-Pentecostal Churches have recently been identified as conducting controversial healing practices such as encouraging their congregants to eat snakes, drink petrol and receive healing through the spraying of Doom (an insecticide).

2 In this sense Masondo (2014:3) notes that 'AICs provide an avenue for African selfdefinition by highlighting what is good about being African and inculcating a sense of pride in their identity'.

3 The approach commonly and previously referred to as Modernisation Theology.

4 Bompani (2010:309) notes that it is by taking African cosmology seriously that African Independent Churches have garnered such popularity.

5 An indigenous South African language and one of South Africa's 11 official languages.

\section{References}

August, Karlie. 2013. 'How Development Ethos Emerges and is Engrained and Sustained in Contact with Local Culture and Religion.' In Religion: Help or Hindrance to Development? Edited by Kenneth Mtata, 69-95. Geneva: Lutheran World Federation.

Bompani, Barbara. 2015. 'Religion and Development in Sub-Saharan Africa: An Overview.' In The Routledge Handbook of Religions and Global Development, edited by Emma Tomalin, 101-113. London: Routledge.

Bragg, W. G. 1987. 'From Development to Transformation' in The Church in Response to Human Need, edited by V. Samuel and C. Sugden, 20-51. Grand Rapids: Eerdmans.

Chambers, Robert. 1997. Whose Reality Counts? Putting the First Last. London: ITP.

Evans, Jeremy, Simon Bekker, Catherine Cross and Gerhardus Cornelis Oosthuizen. 1992. 'Prophets for the Poor: African Independent Churches.' Indicator SA 10, no. 1: 33-37.

Grosfoguel, Ramón. 2007. The Epistemic Decolonial Turn. Cultural Studies 21, no. 2/3: 211-223.

Grosfoguel, Ramon. 2009. A Decolonial Approach to Political-Economy: Transmodernity, Border Thinking and Global Coloniality. Kult 6 - Special Issue Epistemologies of Transformation: The Latin American Decolonial Option and its Ramifications. Fall 2009, 10-38. www.postkolonial.dk/artikler/kult_6/GROSFOGUEL.pdf

Grosfoguel, Ramon. 2011. Decolonizing Post-Colonial Studies and Paradigms of Political-Economy: Transmodernity, Decolonial Thinking, and Global Coloniality. TRANSMODERNITY: Journal of Peripheral Cultural Production of the Luso-Hispanic World, 1(1). 
Hiebert, Paul. 1982. 'The Flaw of the Excluded Middle.' Missiology: An International Review 10, no. 1: 35-47.

Kealotswe, Obed. 2014. 'The Nature and Character of the African Independent Churches (AICs) in the 21st Century: Their Theological and Social Agenda.' Studia Historiae Ecclesiasticae 40, no. 2: 227-242.

Korten, David. 1990. Getting to the 21st Century: Voluntary Action and the Global Agenda. Connecticut: Kumarian Press.

Kritzinger, Johannes J. 1990. 'African Indigenous Churches (AICs) and Development.' Skrif en Kerk 11, no. 1: 48-65.

Litonjua, M. D. 2012. 'Third World/Global South: From Modernization, to Dependency/ Liberation, to Postdevelopment.' Journal of Third World Studies 29, no. 1: 25-56.

Masondo, Sibusiso T. 2014. The African Indigenous Churches' Spiritual Resources for Democracy and Social Cohesion. Verbum et Ecclesia 35, no. 3: 1-15.

Mbaya, Henry and Ntozakhe Cezula. 2016. 'The Contribution of John S. Mbiti to the Study of African Religions and African Philosophy and Biblical Translation.' Paper presented at the conference 'Decolonizing African/Western Knowledge Systems Celebrating the Contribution of Prof. J. S. Mbiti,' Faculty of Theology, University of Stellenbosch, September 2016.

Mbembe, Achille. 2015. 'Decolonizing Knowledge and the Question of the Archive.' Wits Institute for Social and Economic Research (WISER), University of the Witwatersrand, Johannesburg.

McEwan, Cheryl. 2008. Postcolonialism and Development. London: Routledge.

Mignolo, Walter. 2007. Delinking. Cultural Studies. 21(2-3): 449-514. DOI:10.1080/ 09502380601162647

Mtata, Kenneth. 2013. 'Religion and Development: Friends or Foes?' In Religion: Help or Hindrance to Development? Edited by Kenneth Mtata, 23-36. Geneva: Lutheran World Federation.

Myers, Bryant L. 2011. Walking with the Poor: Principles and Practices of Transformational Development. New York: Orbis Books.

Öhlmann, Philipp, Marie-Luise Frost, and Wilhelm Gräb. 2016. 'African Initiated Churches' Potential as Development Actors.' HTS Theological Studies/Teologiese Studies 72, no. 4. http://dx.doi.org/10.4102/hts.v72i4.3825.

Pobee, John S. and Gabriel Ositelu. 1998. African Initiatives in Christianity: The Growth, Gifts and Diversities of Indigenous African Churches: A Challenge to the Ecumenical Movement. Geneva: WCC.

Sachs, Jeffrey. 2012. 'From Millenial Development Goals to Sustainable Development Goals.' Lancet 279: 2206-2211.

Sen, Armatya. 1999. Development as Freedom. Oxford: Oxford University Press.

Spivak, Gayatri Chakravorty. 1994. 'Can the Subaltern Speak?' In Colonial Discourse and Post-Colonial Theory: A Reader, edited by Patrick Willams, and Laura Chrisman. Hertfordshire: Harvest.

Swanepoel, Hennie, and Frik De Beer. 2011. Community Development: Breaking the Cycle of Poverty. Lansdowne: Juta.

Tomalin, Emma. 2013. Religions and Development. London: Routledge.

Wutich, Amber and Melissa Beresford. 2015. 'Community Development in Post-Neo Liberal Bolivia: Decolonisation or Alternative Modernisation?' Community Development Journal: 1-24. 